\title{
Solunum yolu enfeksiyonu bulguları ile başvuran 2 yaş altı çocuklarda respiratory syncytial virus enfeksiyonlarının sıklığı ve klinik özellikleri
}

\author{
Miray KARAKOYUN ${ }^{1}$, Emel AKINCI ATAOĞLU² ${ }^{2}$, Derya BÜYÜKKAYHAN ${ }^{3}$, Murat ELEVLİ²
}

\begin{abstract}
$\ddot{\mathbf{O} z}$
Respiratuar Sinsityal Virüs (RSV) 2 yaş altı süt çocuklarında en önemli alt solunum yolu enfeksiyonu (ASYE) etkenidir. Özellikle 6 aydan küçük süt çocuklarını, prematüreleri, doğumsal kalp hastalığı olanları ve immün sistem hastalığı olan çocukları etkilemektedir. Ayrıca yaştan ve kişiden bağımsız olarak düşük sosyoekonomik düzey, nisan ve eylül arası aylarda doğum, kreș ve yurtlarda kalmak, kalabalık yaşam koşulları, okula giden kardeșin varlığı, sigara dumanına maruziyet, ailede astım ve atopi gibi risk faktörlerine sahip olmak da RSV ye bağlı enfeksiyon ihtimalini artırmaktadır. Çalışmamızda klinik olarak ASYE tanısı konulan 0-2 yaş grubundaki hastaların RSV sıklığının ve klinik özelliklerinin araştırılması amaçlanmıştır. ASYE tanıs 100 hasta çalışmaya alındı. Tekrarlayan hışıltılı solunum öyküsü olan bebekler, eşlik eden ciddi hastalığı bulunanlar, nörolojik ve metabolik bozukluğu olanlar, önceden bilinen immün yetersizliği olanlar, 24 aydan büyük olanlar çalıșma dıșı bırakılmıștır. Hastalardan nazofaringeal sürüntü örneği alınarak RSV respi-strip ile RSV antijeni tarand. RSV pozitif saptanan ve saptanmayan hastalar klinik, laboratuvar, özgeçmiş, aile özellikleri açısından karşılaştırıldı. Hastalarımızda RSV sıklığı \% 63 olarak saptand1. Cinsiyete göre RSV sıklı̆̆ı açısından anlamlı fark saptanmadı. RSV antijeni pozitif saptanan çocukların beslenme ve bakım şekilleri, kardeş sayısı, gelir düzeyi, doğumsal kalp hastalığı, ailede astım öyküsü, evde sigara içilmesi, arasında anlamlı farklılık saptanmadı. RSV, 2 yaş altındaki Türk çocuklarında önemli alt solunum yolu enfeksiyonu nedenidir. Ayrıca süt çocukluğu döneminde özellikle riskli gruptaki hastalarda önemli oranda mortalite ve morbiditeye yol açmaktadır. Nazofaringeal sürüntü örneğinden RSV antijen saptanması uygun ve etkin bir tanı yöntemdir.
\end{abstract}

Yayın Bilgisi

Gönderi Tarihi:06.02.2018

Kabul Tarihi:02.04.2018

Online Yayın Tarihi:30.06.2018

DOI: $10.26453 /$ otjhs.391181

Sorumlu Yazar

Miray KARAKOYUN

Anahtar Kelimeler: Alt solunum yolu, enfeksiyon, RSV, süt çocuğu, tanı

\section{The frequency and clinical characteristics of respiuratory syncytial viirus imfections im children under 2 years with respiratory tract infection}

Miray KARAKOYUN ${ }^{1}$, Emel AKINCI ATAOĞLU² ${ }^{2}$, Derya BÜYÜKKAYHAN ${ }^{3}$, Murat ELEVLİ

\begin{abstract}
Respiratory syncytial virus (RSV) is the most important cause of lower respiratory tract infections ( LRTI ) in infants under 2 years of age. It particularly affects children who have premature birth stories, congenital heart disease or immune system disease and younger than 6 months old. In addition, having low socioeconomic status, crowded living conditions, exposure to cigarette smoke, family history of asthma and atopy increases the risk of RSV infection regardless of. The aim of the study was to investigate the frequency and clinical characteristics of RSV in patients 0-2 years of age who were clinically diagnosed with LRTI in our study. 100 patients who were diagnosed as LRTI were taken into the study. A nasopharyngeal swab was taken from the patients and RSV respi-strip rapid diagnostic kit was used to screen RSV antigen. Patients who were diagnosed as RSV positive and who did not have RSV were compared in terms of clinical, laboratory, resume, family characteristics. RSV frequency in our patients was $63 \%$. There was no significant difference in RSV frequency according to sex. There is a significant difference in nutritional and care patterns of RSV-positive children, number of siblings, history of congenital heart disease, family history of asthma, smoking at home. RSV is a major cause of lower respiratory tract infections in Turkish children under 2 years of age. It also leads to significant mortality and morbidity in infants, especially in the risky group. RSV antigen detection (as a rapid diagnostic method) from a swab specimen is an appropriate and effective diagnostic method.
\end{abstract}

Article Info

Received:06.02.2018

Accepted:02.04.2018

Online Published:30.06.2018

DOI: $10.26453 /$ otjhs.391181

Keywords: Infant, rapid test, lower respiratory tract, infections, RSV

${ }^{1}$ Ege Üniversitesi Tıp Fakültesi, Çocuk Gastroentereoloji, Hepatoloji ve Beslenme Bilim Dalı, İzmir, Türkiye

${ }^{2}$ Haseki Eğitim ve Araştırma Hastanesi, Çocuk Sağlığı ve Hastalıkları Bölümü, İstanbul, Türkiye

${ }^{3}$ İstanbul Medeniyet Üniversitesi, Çocuk Sağlığı ve Hastalıkları Ana Bilim dalı, İstanbul, Türkiye 


\section{GíRiș}

Solunum sinsityal virüsü (RSV; Respiratory syncytial virus), tüm dünyada bebek ve çocuklardaki viral alt solunum yolu enfeksiyonlarının (ASYE) en s1k ve en önemli etkenidir. ASYE bulguları olan herhangi bir yaştaki hastada ayırıcı tanıda mutlaka $R S V$ düşünmelidir 1. Asya, Güney Amerika ve Afrika'daki birçok gelişmekte olan ülkede yapılan çalışmalarda, akut bronşiyolit saptanan çocukların yaklaşık \%33-64'ünden $R S V$ izole edilmiştir. $^{2,3} R S V$ salgınları 1lıman iklimlerde sonbahar sonu, kış ve ilkbahar başında (kasım nisan) görülür. $R S V$ enfeksiyonu, sıklıkla 2 yaş altındaki çocuklarda görülmekte, yarısına yakınında enfeksiyon üst solunum yollarından alt solunum yollarına ilerlemekte ve hastaların yaklaşık \%2'sinin bu nedenle hastaneye

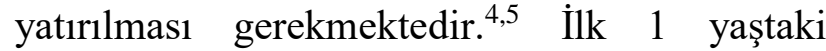
bebeklerin \%50-70 kadarı ve 2 yaşına kadar olan tüm bebeklerin $\% 95$ 'i $R S V$ ile enfekte olmaktadır. Daha sonraki yıllarda $R S V$ 'ye karşı serum antikorlarının gelişmesine rağmen $R S V$ ile reenfeksiyonlar gelişebilmektedir. ${ }^{5,6}$

Prematürite (<36 hf), kronik akciğer hastalığ1, bronkopulmoner displazi, kistik fibrozis, doğumsal kalp hastalığı, immun yetersizlik, gastrointestinal hastalık gibi eşlik eden patolojisi olan hastalar ciddi enfeksiyon için risk faktörü taşımaktadırlar. Ayrıca yaştan ve kişiden bağımsız olarak düşük sosyoekonomik düzey, nisan ve eylül arası aylarda doğum, kreş ve yurtlarda kalmak, kalabalık yaşam koşulları, okula giden kardeşin varlığı, sigara dumanına maruziyet, ailede astım ve atopi gibi risk faktörlerine sahip olmak da $R S V$ 'ye bağlı enfeksiyon ihtimalini artırmaktadır. ${ }^{7}$

$R S V$, bronşiyolit ve bronkopnömoni etkeni olmasının yanında farenjit, konjunktivit, laringotrakeit (krup), akut otitis media nedeni de olabilir. Krup, RSV enfeksiyonlarında çok sık görülmeyen bir klinik tablo olup tüm krup vakalarının \%4'ünden azında neden $R S V$ 'dir. Primer $R S V$ enfeksiyonları veya $R S V$ reenfeksiyonları sırasında akut otitis media da görülebilir. Otitis media oluşumunda iki mekanizma rol oynar; bunlar; a) orta kulağın direk enfeksiyonu, b) östaki tüp disfonksiyonunun kolaylaştırılmasıdır. $R S V$ enfeksiyonlu çocukların \%75'inde orta kulak sıvısında $R S V$ saptanmıştır. $R S V$ orta kulak sıvısında tek başına veya bakteriyel patojenle birlikte izole edilebilir. Bakteriyel patojenle birlikte $R S V$ koenfeksiyonu, otit belirtilerinin uzamasindan ve antibiyotik tedavisine yanıt yetersizliğinden sorumludur. , $^{8,10}$

Ayrıca yaştan ve kişiden bağımsız genel risk faktörleri de vardır. Bunlar düşük sosyoekonomik durum, kalabalık yaşam ortamları, anne sütüyle beslenememe veya az beslenme, çevrede sigara içimi, ailede astım veya atopi öyküsü şeklindedir. ${ }^{11} \mathrm{Bu}$ özelliklere sahip hastalarda da ciddi hastalık yönünden dikkatli davranılmalıdır. Biz bu çalışmamızda; yaşamın ilk 24 ayında ASYE bulgularıyla gelen olgularda $R S V$ bronșioliti sıklığını saptamayı, 
bu hastalarda $R S V$ tanisal testlerinin rutin bakılıp bakılmaması gerektiğini belirlemeyi, bulgularının özelliklerini ve prognozu belirlemeyi amaçladık.

\section{MATERYAL ve METOT}

Hastanemizin çocuk poliklinik ve acil birimine akut bronşiyolit, bronkopnömoni tablosuyla başvuran, uzun süreli yatarak tedavi gereksinimi olmadan acilden taburcu edilen veya süt çocuğu servisine yatırılan 1-24 ay arasındaki 100 bebek çalışmaya alınmıştır. Çalışma 6 ay sürmüştür.

Tekrarlayan hış1ltılı solunum öyküsü olan bebekler, eşlik eden ciddi hastalığı bulunanlar (sepsis, menenjit vb.), ciddi nörolojik ve metabolik bozukluğu olan bebekler, daha önceden bilinen immün yetersizliği olan çocuklar, yaşı 24 aydan büyük olanlar ve ailenin onamının alınamadığı bebekler çalışma dışı bırakılmıştır.

Çalışma grubundaki hastaların anamnezleri ayrıntılı olarak ailelerinden alındı. Anamnez bilgileri olarak yas, cinsiyet, başvuru anındaki şikayetleri, şikayetlerinin başlangıç süresi, ailedeki fert sayısı, kardeş sayıları, çocuğun bakımını birincil olarak kimin üstlendiği ve bakım koşulları, beslenme anamnezi, çocuğun ek hastalığının olup olmadığı ve fizik muayene bulguları kaydedildi. Çalışmaya alınan hastalardan nasofarengeal sürüntü örnekleri alındı. Nazofaringeal sürüntü yöntemleriyle numune alınırken test sonucunu etkileyebileceği için kanlı numuneler çalışmaya alınmadı.
Örnekler alındıktan hemen sonra zaman kaybedilmeden Smartest Diagnostics RSV Strip markalı hızlı immunokromatografik test ile kliniğimiz acil laboratuvarında prospektüs bilgilerine uyularak çalışıldı. Test sonuçları çalışma formuna kaydedildi. Çalışmamızın yürütülebilmesi için hastanemiz etik kurulundan onay alınmıştır.

\section{İstatistiksel Íncelemeler}

İstatistiksel analizler için NCSS (Number Cruncher Statistical System) 2007\&PASS 2008 Statistical Software (Utah, USA) programı kullanıld1. Normal dağılım gösteren parametrelerin iki grup arasi karşılaştırmalarında Student $\mathrm{t}$ test, normal dağılım göstermeyen parametrelerin iki grup arası karşılaştırmalarında Mann Whitney U test kullanıldı. Niteliksel verilerin karşılaştırılmasında ise Ki-Kare testi ve Fisher's Exact testi kullanıldı. Anlamlılık $\mathrm{p}<0.05$ düzeyinde değerlendirildi.

\section{BULGULAR}

Çalışmaya 44'ü (\%44) kız, 56’sı (\%56) erkek olmak üzere toplam 100 çocuk dahil edildi. En fazla Ekim (\%29) ve Aralık (\%28) ayında örnek alınd1.

Çocukların yaşları 1 ile 24 ay arasında değişmekte olup, ortalama yaş 7,66 55,49 aydır. Çocukların \%63'ünde $\quad R S V$ pozitifliği, \%56'sında ateş, \%4'ünde öksürük, \%58'inde burun akıntısı, \%74'ünde hiriltılı solunum, \%58'inde solunum sıkıntısı, tümünde de bulantı 
görülmektedir. Çocukların 9'unda Dispne, 3'ünde Takipne-Dispne, 49'unda Wheezingkrepitasyon görülmekte olup, 39 çocukta bu bulguların tümü görülmektedir. Çocukların 39'unda CRP pozifliği, 14'ünde malnütrisyon varlığı, 9'unda yenidoğan döneminde surfaktan tedavisi uygulanması, 27'sinde yoğun bakımda yatış, 14'ünde de ventilatör uygulaması öyküsü vardı. Hastaların tamamlayıcı özellikleri aşağıdaki tabloda verilmektedir (Tablo 1) .

Çocukların 89'unda ek hastalık bunların da 16'sında doğumsal kalp hastalığı, 32'sinin ailesinde alerji, 28'inin ailesinde astım öyküsü vardı, 61'inin babası sigara kullanmaktaydı. $R S V$ pozitif olan hastalar diğer hastalarla karşılaştırıldığında solunum sıkıntısı ve hırıltılı solunum bulgularının $R S V$ pozitif olan hastalarda daha sık ve ağır olduğu, ayrıca prematürite oranının daha yüksek olduğu saptanmıştır. $R S V$ pozitif ve negatif olan hastaların tanımlayıcı ve klinik özellikleri aşağıdaki tablolarda verilmiştir (Tablo 3 ve Tablo 4).

$R S V$ pozitifliğine göre anne eğitim düzeyleri arasında istatistiksel olarak anlamlı farkl11ık bulunmaktadır $(\mathrm{p}<0,05)$; ilköğretim mezunu annelerin çocuklarında $R S V$ oranı yüksekken, lise mezunu annelerin çocuklarında $R S V$ görülmeme oranı yüksektir (Şekil 1). RSV pozitifliğine göre kardeş sayıları arasında istatistiksel olarak anlaml farklılık bulunmaktadır $(\mathrm{p}<0,01)$; kardeş sayısı arttıkça $R S V$ görülme oranı da artmaktadır. Evdeki kişi sayısı, 1sınma tipi, oda sayısı ve gelir düzeyi ile arasında anlamlı farklılık saptanmamıştır.

$R S V$ pozitifliğine göre ateş, öksürük ve burun akıntısı görülme durumları, CRP düzeyleri arasında istatistiksel olarak anlamlı farklılık bulunmamakta iken ( $\mathrm{p}>0,05) ; R S V$ pozitif grupta hırılt1lı solunum ( $p<0,05$ düzeyinde) ve solunum sıkıntısı ( $<<0,01$ düzeyinde) görülme oranları anlamlı şekilde yüksektir. $R S V$ varlığı durumuna göre şikayetlerin dağılımı aşağıdaki grafikte gösterilmektedir (Şekil 2).

$R S V$ pozitifliğine göre bakım şekilleri arasında istatistiksel olarak anlamlı farklılık bulunmaktadır $(p<0,01)$; kreşe giden ve anne dışında başkası tarafından bakılan çocuklarda $R S V$ görülme oranı yüksekken, annesi tarafindan bakılan çocuklarda $R S V$ görülmeme oranı yüksektir. $R S V$ pozitifliğine göre beslenme şekilleri arasında istatistiksel olarak anlamlı farklılık bulunmaktadır $(\mathrm{p}<0,01)$; anne sütü almayan çocuklarda $R S V$ görülme oranı yüksekken, anne sütü alan çocuklarda $R S V$ görülmeme oranı yüksektir.

Doğumsal kalp hastalığ̣ ya da başka bir ek kronik hastalığı olan, yoğun bakımda yatış ve surfaktan kullanımı öyküsü olan, ailesinde sigara kullanımı ya da alerji ve astım öyküsü olan ayrıca malnütrisyonu olan çocuklarda $R S V$ görülme oranı istatistiksel olarak anlamlı şekilde yüksektir $(\mathrm{p}<0,01)$ (Tablo 4). 


\section{TARTIŞMA}

Çocukların \% 95'inden fazlasının ilk 2 yaşta $R S V$ ile enfekte olduğu tahmin edilmektedir. ${ }^{12}$ $R S V$ erişkinlerde soğuk algınlığı şeklinde hastalık yaparken, bebek ve çocukların \%40'ında 2-5 gün içinde alt solunum yollarına ilerlemektedir. ABD'de 5 yaşın altındaki hastalar ile yapılmış yeni bir araştırmada, radyografik olarak pnömoni teşhis konan hastalar arasında $R S V$ en önemli patojen olarak tespit edilmiştir. ${ }^{13}$

Çalışmamızda, 0-24 ay arasındaki ASYE'lu infantlarda yaptığımız taramada $R S V$ enfeksiyon sıklığını \%63 bulduk. Ülkemizde 1990’1ı yıllardan beri RSV enfeksiyon sıklığını farklı gruplarda, farklı tanısal testlerle belirleyen pek çok klinik çalışma yapılmıştır. Bu çalışmalarda $R S V$ enfeksiyon sıklıkları \%20-\%63 arasında rapor edilmiştir. Kanra ve arkadaşlarının 2005 yılında yayınlamış oldukları çok merkezli bir çalışmada $R S V$ enfeksiyon sıklığı \% 29,5 olarak saptanmıştır. ${ }^{14} R S V$ enfeksiyon sıklığını \%45.3 olarak en yüksek Van'da rapor etmişlerdir. Van'dan sonra en s1k \%39,1 olarak Ankara'da $R S V$ enfeksiyonu saptanmıştır. ${ }^{14}$ Çalışmamızda $R S V$ enfeksiyon sıklığını literatüre göre oldukça yüksek bulmamız olgularımızın düşük sosyoekonomik düzeyde olmalarından kaynaklanıyor olabilir. $R S V$ enfeksiyon sıklığı coğrafik bölgeye göre değişir ve $R S V$ salgınları 1lıman iklimlerde sonbahar sonu, kış ve ilkbahar başında (Kasım-Nisan) görülür. Kanra ve arkadaşlarının çalışmasında ülkemizde $R S V$ enfeksiyonunun en sık görüldüğü dönem Kasım ve Mart ayları arasında bildirilmiştir. ${ }^{14}$ Çalışmamızın Eylül ve Ocak ayları arası $R S V$ enfeksiyon sezonunda yapılmış olması da enfeksiyon sıklığının bu kadar yüksek bulunmasının nedeni olabilir. Çalışmamızın coğrafik bölge olarak 1lıman iklimde olan İstanbul'da yürütülmesine rağmen enfeksiyon sıklığının bu kadar yüksek olması dikkat çekicidir.

İstanbul'da yapılmış olan çalışmalar değerlendirildiğinde Kayıran ve arkadaşları sosyoekonomik düzeyi yüksek hastalarda $R S V$ enfeksiyon sıklığını \%20 bulmuşlardır. ${ }^{15}$ Hatipoğlu ve arkadaşlarının yapmış oldukları çalışmada da $R S V$ sıklığı \%35 saptanmıştır. ${ }^{16}$ Nişli ve arkadaşları da İstanbul'da RSV IgG antikor pozitifliğini \%52 bulmuşlardır. ${ }^{17} 2006$ yılında Erten ve arkadaşlarının İstanbul'daki çalışmasında bronşiolitli infantlarda $R S V$ sıklığ \%63 olarak rapor edilmiş olup bizim bulgumuzla birebir uyumludur. ${ }^{18}$ İstanbul coğrafik bölge olarak $R S V$ enfeksiyonu yönünden riskli bölge olmamakla birlikte, yoğun nüfus oranı ve düşük sosyoekonomik düzeydeki hasta grubunun fazla olması nedeniyle süt çocukları yönünden $R S V$ tehdit unsurudur. $R S V$, morbiditesi yüksek olan nazokomiyal enfeksiyonlara neden olabilir. Bronşiolitli süt çocuklarında $R S V$ taramasının rutin olarak yapılması, olguların saptanmasında yarar sağlayabilecektir. 
$R S V$ 'ye bağlı ASYE olan çocuklarda tanı, klinik ve epidemiyolojik bulgular temel alınarak konulur. Ancak kesin tan1, hastaların solunum yollarından alınan örneklerden hücre kültürü ve shell-vial testleri ile virüsün izolasyonu ile olmaktadır. Ancak virus izolasyonunda yalancı negatif sonuçlar alınabilmekte ve karakteristik sitopatik etkinin 3-7 günde ortaya çıkmasından dolayı klinik uygulamada yarar sağlamamaktadır. Viral enfeksiyonların tanısında kullanılan antijen tayinleri hızlı sonuçlar açısından avantajlıdır. $R S V \quad \operatorname{IgM}$ antikorlarının hastalık bulguları başladıktan 5-8 gün sonra ortaya çıkması ve hastalığın başlangıç döneminde kanda saptanmaması nedeniyle tanı amaçlı antikor bakılması da önerilmez. Dereli ve arkadaşları İzmir'de hücre kültürü ve direk floresan antikor yöntemiyle $R S V$ pozitifliğini $\% 29,2$ olarak rapor etmişlerdir. ${ }^{19}$ Sayıner ve arkadaşları direk floresan antikor testi ile $R S V$ sıklığını \%21,9, Özacar ve arkadaşları da enzim floresan immün asssay yöntemiyle \%36,4 antijen pozitifliği saptamışlardır. ${ }^{20,21}$

$R S V$ enfeksiyonları kız ve erkeklerde yaklaşık olarak eşit sıklıkta görülmekte ancak erkeklerde daha ağır seyretmektedir. Hatipoğlu ve arkadaşlarının yaptığ 1 bir çalışmada erkeklerde $\% 32,5$, k1zlarda $\% 62,5$ oranında $R S V$ pozitifliği vardır. $^{16}$ Kayıran ve arkadaşlarının yaptığı çalışmada $R S V$ pozitif olguların \%44 ü kız \%56 s1 erkekti ve $R S V$ pozitifliği ile cinsiyet arasında anlamlı bir ilişki bulunamadı. ${ }^{15}$ Bizim çalışmamızda da $R S V$ pozitif hastaların \%54 ü erkek, \%46'sı kızdı ve $R S V$ pozitifliği ile cinsiyet arasında anlamlı bir ilişki bulunamadı.

Kalabalık ortamda yaşayan ve evdeki kardeş sayısı fazla olan süt çocukları $R S V$ ile daha sık karşılaşmaları ve daha fazla viral yüke sahip olmaları nedeniyle enfeksiyonlar açısından büyük bir risk altındadırlar. Kanra ve arkadaşlarının yaptığı çalışmada, kalabalık aile yapısı ya da kardeş sayısıyla $R S V$ pozitif ve negatifliği arasında anlamlı bir istatistiksel ilişki saptanmamıştır. ${ }^{14}$ Hatipoğlu ve arkadaşlarının yaptığı bir çalışmada ise kardeş sayısı ile $R S V$ pozitifliği arasında anlamlı olarak istatistiksel bir ilişki saptanmıştır. ${ }^{16}$ Çalışmamızda kardeş sayısı ile $R S V$ pozitifliği arasında istatistiksel olarak anlamlı bir sonuç bulunmuş; ancak evdeki kişi sayısı ve $R S V$ pozitifliği arasında istatistiksel olarak anlamlı bir sonuç bulunamamıştır.

Pasif sigara içimine maruz kalmanın özellikle süt çocuklarında önemli bir risk faktörü olduğu bilinmektedir. Hatipoğlu ve arkadaşlarının yaptığı çalışmada annelerin sigara içme oranı \%55, babaların sigara içme oranı \%70'in üzerinde bulunmuş ancak $R S V$ pozitifliği ile sigara içimi arasında anlamlı bir sonuç bulunamamıștır. ${ }^{16}$ Yine Kanra ve arkadașlarının yaptığı çalışmada $R S V$ pozitiflerin \%54'ünün, $R S V$ negatiflerin ise \%49'unun pasif sigara içimine maruz kaldığı belirlenmiş ve $R S V$ pozitifliği ile sigara içimi arasında anlamlı bir ilişki saptanmamıștır. ${ }^{14}$ Bizim çalışmamızda ise $R S V$ pozitif olgularda sigara içme öyküsü $\% 81$ 
iken, $R S V$ negatif olgularda sigara içme öyküsü \%27 saptandi. RSV enfeksiyonlarından korunmada; en önemli üç unsurun el yıkama, kalabalık ortamdan uzak durma ve sigaraya maruz kalmanın önlenmesi olduğu pek çok klinik çalışmada ortaya konmuştur. Sigara ile $R S V$ arasında anlamlı ilişki literatürdeki pek çok çalışmayla uyumluluk göstermektedir. ${ }^{14,16}$

Altta yatan konjenital kalp hastalığı ya da malnütrisyon, ailede astım ve alerji öyküsü olan hastalar ASYE açısından büyük risk altındadırlar. Kanra ve arkadaşlarının yaptığı çalışmada ek hastalık ile $R S V$ pozitifliği arasında anlamlı bir ilişki bulunamamışken, çalışmamızda istatistiksel olarak anlamlı bir sonuç bulunmuştur. ${ }^{14}$ Sonucumuz Kanra ve arkadaşlarının sonucuyla uyumlu olmamakla birlikte literatürdeki diğer çalışmalarla uyumludur. ${ }^{15,16,17}$ Malnütrisyon, ailede astım ve ailede alerji öyküsü durumlarında da $R S V$ pozitif ve $R S V$ negatif gruplar arasında anlamlı farklılık bulundu.

Anne sütü $R S V$ için önemli bir koruyucu etmendir. Çalışmamızda, literatürde 16,22 belirtilen sonuçlar ile uyumlu olarak anne sütüyle beslenme $R S V$ negatif grupta anlamlı olarak yükssek saptanmıştır. Hatipoğlu ve arkadaşlarının yaptığı çalışmada CRP pozitifliği $R S V$ pozitif olan grupta $R S V$ negatif olan gruba göre anlamlı derecede yüksek iken, bizim çalışmamızda anlamlı bir ilişki saptanmadı. ${ }^{17}$
Hastalarımızda en fazla görülen yakınmalar sirasiyla; \%52 hirilt1lı solunum ,\%43 solunum sıkıntısı, \%37 burun akıntısı, \%24 ateş, \%4 öksürüktü. En sık başvuru semptomları; Erten ve $\operatorname{arkadaşlarının~}^{18}$ yaptığı çalışmada ateş, baş ve kas ağrısı Narlı ve arkadaşlarının ${ }^{23}$ çalışmasında burun akıntısı Tanır ve $\operatorname{arkadaşlarının~}^{24}$ yaptığı çalışmada öksürük, burun tıkanıklı̆̆ı, ateş Hatipoğlu ve arkadaşlarının ${ }^{16}$ yaptığg çalışmada ise öksürük ve hırıltıydı. Bizim çalışmamız Erten ve arkadaşlarının yaptıkları çalışma ile uyumsuz, Tanır, Hatipoğlu, Narlı ve arkadaşlarının yaptığ 1 çalışma ile uyumluydu. ${ }^{16,18,23,24}$

Hatipoğlu ve arkadaşlarının yaptığı çalışmada \%21,3 olguda prematüre doğum öyküsü mevcuttu. Bizim çalıșmamızda da annelerin gebelik yaşı ortalaması $37.09+-3,1$ di ve $R S V$ pozitif grubun annelerinin gebelik yaş ortalaması, $R S V$ negatif grubun gebelik yaşı ortalamasına göre istatistiksel olarak anlamlı derecede düşüktü.

$R S V$ 'ye bağlı akut bronşiyolit bazı risk faktörü taşıyan bebeklerde daha ciddi klinik tablo ve daha yüksek mortalite oranına sebep olabilir. Daha önceden sağlıklı olup hastaneye yatıșı gerektiren bebeklerde mortalite \% 0.5-1 iken ciddi kardiyak bozukluğu olanlarda \% 3-33, ciddi prematüre ve altta akciğer hastalığı olan bebeklerde ise \% 3-5 arasındadır. ${ }^{25,26,27}$ 


\section{SONUÇ}

$R S V, 2$ yaş altındaki Türk çocuklarında önde gelen ASYE nedenidir. Ayrıca süt çocukluğu döneminde özellikle riskli gruptaki hastalarda önemli mortalite ve morbiditeye yol açmaktadır. Çalışmamızda hastalarımızın prognozu genel olarak iyiydi. Nazofarengeal fırça ile alınan sürüntü örneğinden $R S V$ antijen saptanması (hızlı tanı yöntemi olarak) uygun ve etkin bir yöntemdir.

\section{KAYNAKLAR}

1. Brief report: Respiratory syncytial virus activity-United States, 2004- 2005. MMWR. 2005; 54: 1259-60.

2. Kyu HH, Pinho C, Wagner JA, Brown JC, Bertozzi-Villa A, et al. Global and National Burden of Diseases and Injuries Among Children and Adolescents Between 1990 and 2013: Findings From the Global Burden of Disease 2013 Study. JAMA Pediatr. 2016; 170 (3): $267-87$.

3. Williams BG, Gouws E, Boschi-Pinto C, Bryce J, Dye C. Estimates of world-wide distribution of child deaths from acute respiratory infections. Lancet Infect Dis. 2002; 2 (1): 25-32.

4. McIntosh K. Respiratory Syncytial Virus. Evans A S,Kaslow RA eds. In: Viral Infections of Humans Epidemiology and Control $4^{\text {th }}$ ed. Boston, Springer, 1997: 691-711.
5. Borchers AT, Chang C, Gershwin ME, Gershwin LJ. Respiratory syncytial virus-a comprehensive review. Clin Rev Allergy Immunol. 2013; 45 (3): 331-379.

6. Panda S, Mohakud NK, Suar M, Kumar S. Etiology, seasonality, and clinical characteristics of respiratory viruses in children with respiratory tract infections in Eastern India. J Med Virol. 2017; 89 (3): 553-558.

7. Hall CB, Weinberg GA, Iwane MK, Blumkin AK, Edwards KM, Staat MA, et al. The burden of respiratory syncytial virus infection in young children. $\mathrm{N}$ Engl $\mathrm{J}$ Med. 2009; 360(6): 588-598.

8. Hall C.B, Mc Carthy C.A: Respiratory syncytial virus. In: Mandell G.L, Bennett J.E, Dolin R. Principles and Practice of Infectious Diseases 4 th. edition Churchill Livingstone. 1995; 1501-1509.

9. Lindgren C, Lin J, Graham B.S, Gray M.E, Perker R.A, et al. Respiratory syncytial virus infection enhanced the response to laryngeal chemostimulation and inhibits arousal from sleep in young lambs. Acta Pediatr. 1996; 85: 789-797.

10. Arola M, Ruuskanen O, Thedi Z, Mertsola J, Salonene K.N. Clinical role of respiratory virus infection in acute otitis media. Pediatrics. 1990; 85: 798-803.

11. Simoes EA: Respiratory syncytial virus infection. Lancet. 1999; 354 (4): 847-52. 
12. Griffiths C, Drews SJ, Marchant DJ. Respiratory syncytial virus: infection, detection, and new options for prevention and treatment. Clin Microbiol Rev. 2017; 30(1):277-319.

13. Jain S, Williams DJ, Arnold SR, Ampofo K, Bramley AM, Reed C, CDC EPIC Study Team. Community-acquired pneumonia requiring hospitalization among U.S. children. N Engl J Med. 2015; 372(9): 835845.

14. Kanra G,Tezcan S,Yilmaz G and Turkish National Respiratory Syncytial Virus (RSV) Team: Respiratory syncytial virus epidemiology in Turkey. Turk $\mathbf{J}$ Pediatr. 2005; 47(4): 303-8.

15. Kayıran M,Paloğlu E.,Günakan B. Bronşiolit tanısıyla izlenen küçük çocuklarda RSV sıklığı, klinik ve laboratuar özellikleri. Türk Pediatri Arşivi. 2010; 45: 252-6.

16. Hatipoğlu S, Arıca S, Çelik Y, Öztora S, ŞevketoğluE, Erkum T. Alt solunum yolu enfeksiyonu tanısıyla hastanemize yatırılan olgularda RSV enfeksiyonu sıklığı ve klinik özellikleri. Düzce Tıp Dergisi. 2009; 11(1): $38-44$.

17. Nisli K, Önes Ü, Güler N, Tamay Z. Hısıltılı süt çocuklarında RSV antikorları, lökotrien E4 ve total IgE düzeyleri. Çocuk Dergisi. 2004; 4: 33-36.

18. Erten M, Karayağar N, Ergüven M, Okumuş Ö, Aksu N, Çakı S, Aydın H, Özgüneş N. Bronşiyolitli olgularımızda respiratuvar sinsityal virüs (RSV) infeksiyonu sıklı̆̆ının değerlendirilmesi. Göztepe Tıp Dergisi. 2006; 21(3): 113-115.

19. Dereli D, Ertem E, Serter D, Sadiment M, Çoker M, Tanaç R. Detection of respiratory syncytial virus in children in 1993-1994 winter season in İzmir, Turkey, by two diagnostic methods. APMIS. 1994; 102: 877-880.

20. Sayıner A.A, Erbaycı O.Ö, Yüksel H, Zeytinoglu A, Tanaç R, Bilgiç A. Alt solunum yolu enfeksiyonlu çocuklarda solunum virüsları antijenlerinin araştırılması. 8. Türk Klinik Mikrobiyoloji ve İnfeksiyon Hastalıkları Kongresi Özet Kitabı 1997. S:363.

21. Özacar T, Zeytinoglu A, Özdogru E, Aydemir S, Tanaç R., Bilgiç A. Alt solunum yolu ekfeksiyonu olan çocuklarda respiratuar sinsityal virüs antijeninin arastırılması. İnfeks. Derg.1996; 10: 25-27.

22. Oddy WH, Sly PD, de Klerk NH, et al. Breast feeding and respiratory morbidity in infancy: a birth cohort study. Arch Dis Child. 2003; 88(3): 224-8.

23. Narlı N, Yapıcıŏglu H, Sartar M, Pekmezci D, Yarkın F. Yenidoğan yoğun bakım ünitesinde solunum sinsityal virüs infeksiyonu. Turkish Journal of Infection. 2001; 15(1): 161-165.

24. Tanır G, Doğru Ü, Uzunali Ö, Akar N. Viral alt solunum yolu enfeksiyonu bulgulari olan bebeklerde respiratory syncytial virüs (RSV) 
enfeksiyonlarinin sikliği ve klinik özellikleri. T Clin J Pediatry. 2000; 9(1): 93-7.

25. Openshaw PJM. Potential therapeutic implications of new insights into respiratory syncytial virus disease, Respir Res. 2002; 3(1): $15-20$.

26. Shay D.K, Holman R.C, Roosvelt G.E, Clarke M.J, Anderson L.J. Bronchiolitis associated mortality and estimates of respiratory syncytial virus-associated deaths among US children, 1979-1997. J Infect Dis. 2001; 183(1): 16- 22.

27. Wang EE, Law BJ, Stephens D. Pediatric Investigators Collaborative Network on Infections in Canada (PICNIC) prospective study of risk factors and outcomes in patients hospitalized with respiratory syncytial viral lower respiratory tract infection. J Pediatr. 1995; 126(2): 212-9. 
Tablo 1:Tanımlayıcı Özelliklerin Dağılımı

\begin{tabular}{|c|c|c|c|}
\hline \multicolumn{2}{|l|}{ Değişkenler } & Min-Max & Ort \pm SS \\
\hline \multicolumn{2}{|l|}{ Ağırlık (gr) } & $2000-15000$ & $7299,39 \pm 2793,24$ \\
\hline \multicolumn{2}{|l|}{ Boy $(\mathrm{cm})$} & $42-82$ & $65,72 \pm 9,05$ \\
\hline \multicolumn{2}{|c|}{ Doğum Ağırlığı (gr) } & $1000-4100$ & $2972,40 \pm 677,51$ \\
\hline \multicolumn{2}{|c|}{ Doğum haftası (ay) } & $27-41$ & $37,70 \pm 2,71$ \\
\hline \multicolumn{2}{|l|}{ WBC } & $1000-26500$ & $11452,60 \pm 4796,90$ \\
\hline & & $\mathrm{n}$ & $\%$ \\
\hline \multirow[t]{2}{*}{ Cinsiyet } & Kiz & 44 & 44 \\
\hline & Erkek & 56 & 56 \\
\hline \multirow[t]{2}{*}{ Ağırlık Persantil } & $<3$ Pers & 40 & 40 \\
\hline & 3-95 Pers & 59 & 59 \\
\hline
\end{tabular}

Tablo 2: RSV Pozitifliğine Göre Şikayetlerin Değerlendirmesi

\begin{tabular}{|c|c|c|c|c|}
\hline \multirow[b]{2}{*}{ Değişkenler } & & \multicolumn{2}{|c|}{$R S V$} & \multirow[t]{2}{*}{$\mathrm{p}$} \\
\hline & & Pozitif & Negatif & \\
\hline Ateş & & $24(\% 38,1)$ & $20(\% 54,1)$ & 0,121 \\
\hline Öksürük & & $4(\% 6,3)$ & $0(\% 0)$ & 0,294 \\
\hline Burun Akıntıs1 & & $37(\% 58,7)$ & $21(\% 56,8)$ & 0,847 \\
\hline Hirilt1li Solunum & & $52(\% 82,5)$ & $22(\% 59,5)$ & $0,011^{*}$ \\
\hline Solunum Sikintıs & & $43(\% 68,3)$ & $15(\% 40,5)$ & $0,007 * *$ \\
\hline \multirow{3}{*}{ Bulantı Zamanı } & 0-3 gün & $42(\% 66,7)$ & $25(\% 67,6)$ & 0,981 \\
\hline & 4-7 gün & $17(\% 27)$ & $10(\% 27)$ & \\
\hline & 8. gün ve sonras1 & $4(\% 6,3)$ & $2(\% 5,4)$ & \\
\hline
\end{tabular}


Tablo 3: $R S V$ pozitifliğine Göre Tanımlayıcı Özelliklerin Değerlendirmesi

$R S V \quad \mathrm{p}$

Değişkenler

Pozitif Negatif

Ort \pm SS (Medyan) $\quad$ Ort \pm SS (Medyan)

\begin{tabular}{|c|c|c|c|c|}
\hline \multicolumn{2}{|l|}{ Yaş (ay) } & $8,18 \pm 6,04(7)$ & $6,78 \pm 4,35(6)$ & 0,450 \\
\hline \multicolumn{2}{|l|}{ A ğırlık (gr) } & $7299,0 \pm 3030,4$ & $7300,0 \pm 2361,8$ & 0,999 \\
\hline \multicolumn{2}{|l|}{ Boy $(\mathrm{cm})$} & $65,79 \pm 10,17$ & $65,62 \pm 6,90$ & 0,922 \\
\hline \multicolumn{2}{|c|}{ Doğum Ağırlığı (gr) } & $2840,6 \pm 755,0$ & $3196,7 \pm 445,4$ & $0,004 * *$ \\
\hline \multicolumn{2}{|l|}{ WBC } & $11880,0 \pm 4291,3$ & $10724,8 \pm 5540,6$ & 0,247 \\
\hline \multirow{2}{*}{\multicolumn{2}{|c|}{ Doğum haftası (ay) }} & $37,09 \pm 3,10$ & $38,73 \pm 1,36$ & $0,001 * *$ \\
\hline & & $\mathrm{n}(\%)$ & $\mathrm{n}(\%)$ & \\
\hline \multirow[t]{2}{*}{ Cinsiyet } & $\mathrm{K} 1 \mathrm{z}$ & $29(\% 46,0)$ & $15(\% 40,5)$ & 0,593 \\
\hline & Erkek & $34(\% 54,0)$ & $22(\% 59,5)$ & \\
\hline \multirow[t]{3}{*}{ Ağırlık Pers. } & $<3$ Pers & $40(\% 63,5)$ & $19(\% 51,4)$ & 0,322 \\
\hline & 3-95 Pers & $22(\% 34,9)$ & $18(\% 48,6)$ & \\
\hline & $>95$ Pers & $1(\% 1,6)$ & $0(\% 0)$ & \\
\hline \multirow[t]{2}{*}{ Boy Pers. } & $<3$ Pers & $44(\% 69,8)$ & $21(\% 56,8)$ & 0,185 \\
\hline & 3-95 Pers & $19(\% 30,2)$ & $16(\% 43,2)$ & \\
\hline
\end{tabular}


Tablo 4: RSV Pozitifliğine Göre Ek Hastalık ve Ailede Hastalık Değerlendirmesi

$R S V$

Değişkenler

Pozitif

Negatif

$\mathrm{p}$
n $(\%)$
$\mathrm{n}(\%)$

Ek Hastalık

$16(\% 25,4)$

$3(\% 8,1)$

$0,033^{*}$

Doğumsal Kalp Hastalığ

$15(\% 23,8)$

$1(\% 2,7)$

$0,005^{* *}$

Malnütrisyon

$12(\% 19)$

$2(\% 5,4)$

$0,048^{*}$

Ailede Alerji

$25(\% 39,7)$

$7(\% 18,9)$

$0,032 *$

Ailede Astım

$23(\% 36,5)$

$5(\% 13,5)$

$0,013 *$

Ailede Sigara (baba)

$51(\% 81)$

$10(\% 27)$

$0,001 * *$ 
RSV Durumuna Göre Şikayetlerin Dağıımı

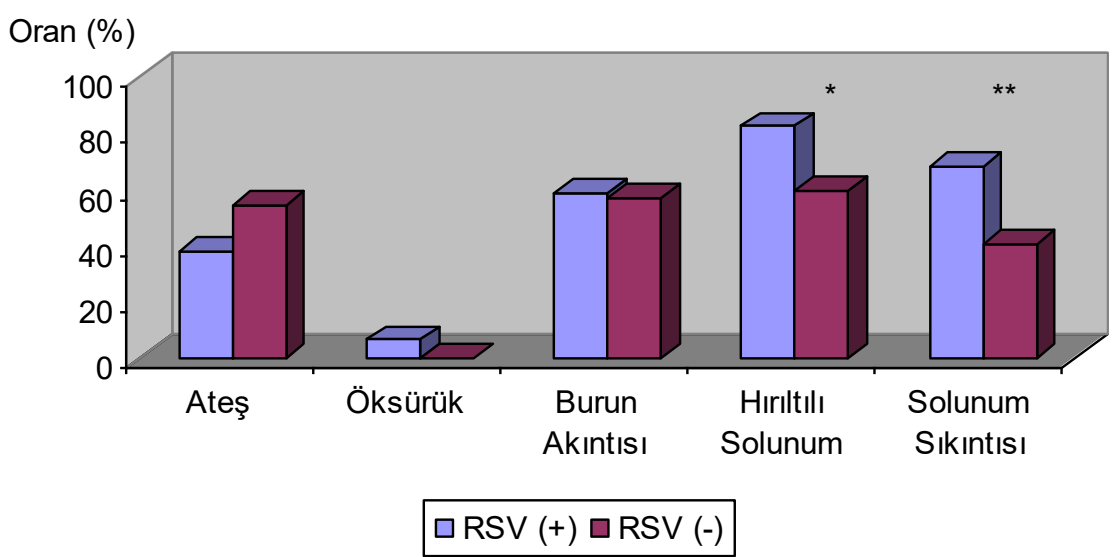

Şekil 1. RSV durumuna göre anne eğitim düzeyleri dağılımı

\section{RSV Durumuna Göre Anne Eğitim Düzeyleri}

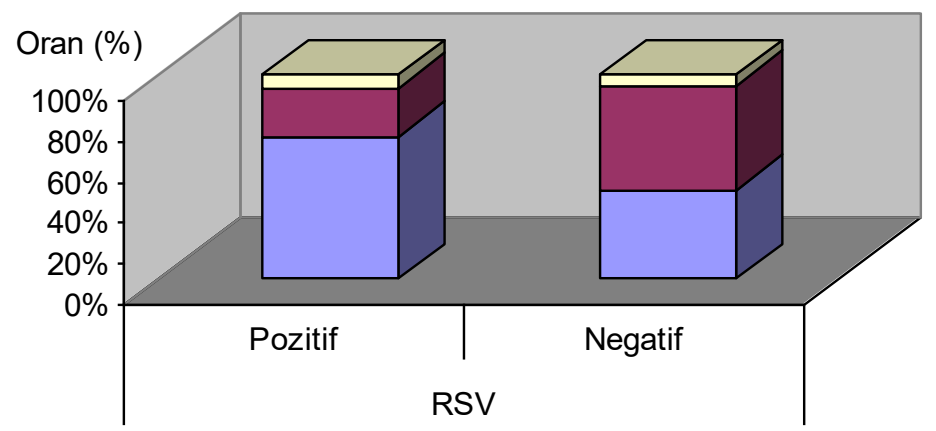

Anne Eğitim Durumu $\square$ İlköğretim $\square$ Lise $\square$ Lise Üzeri

Şekil 2. RSV durumuna göre şikayetlerin dağılımı 